\title{
HER2 Reseptörüne Karşı Geliştirilen DNA Aptamerlerin Meme Kanserinde Tanı ve Tedavi Amaçlı Kullanılması
}

\author{
Fulya KÜÇÜKCANKURT ${ }^{1}$, Nedret ALTIOK
}

\begin{abstract}
$\ddot{O} \mathbf{z}$
Bu çalışmada, HER2-pozitif (HER2+) meme kanser hücrelerinde biyobelirteç olarak HER2 reseptörünü hedef alan DNA aptamerler kullanarak ileride HER2+ kanser hücrelerine selektif diyagnostik testler geliştirmeyi ve sitotoksik ilaçları hedefe yönelik bir şekilde kanser hücrelerine taşımayı amaçladık. Gastrik tümör hücrelerinde HER2 yüzey antijenlerini tanıdığı bildirilen monomerik ve trimerik HER2 DNA aptamer sekanslarının HER2+ meme kanser hücrelerine selektif olarak bağlanıp bağlanmadığını test ettik. Bu nedenle HER2 DNA aptamer sekansların 5 ucuna IRD 800 bağlanarak işaretlendi. IRD 800 işaretli monomerik ve trimerik HER2 DNA aptamer sekanslarının meme kanser hücrelerinde HER2 reseptörlerini hedefleme yetenekleri karşılaştırıldı. Buna göre, HER2 reseptör protein düzeylerine paralel olarak, IRD 800 işaretli DNA aptamer sekansları yüksek oranda HER2 ekspresyonu görülen MDA MB 453 ve SKBR3 meme kanser hücrelerine yoğun şekilde bağlanırken, hiç HER2 ekspresyonu görülmeyen MDA MB 231 hücrelerine çok az spesifik olmayan bağlanma görüldü.
\end{abstract}

Anahtar Kelimeler: Aptamer, Antikanser ilaç, Meme kanseri, HER2, Florofor

\section{Application of DNA Aptamers against HER2 receptors in the Diagnosis and Treatment of Breast Cancer}

\begin{abstract}
Here we aim to develop DNA aptamers targeting HER2 receptors as biomarker in HER2positive (HER2+) breast cancer cells to develop diagnostic tests and to deliver cytotoxic drugs to cancer cells in a tumor-specific manner in the future. We have tested whether the monomeric and trimeric HER2 DNA aptamer sequences which have been reported to recognize HER2 surface antigens in gastric tumor cells selectively bind to HER2+ breast cancer cells. For this purpose we labeled 5' ends of HER2 DNA aptamer sequences with IRDye 800. Then we have compared the abilities of these IRDye 800 labeled monomeric and trimeric HER2 DNA aptamer sequences to target HER 2 receptors in breast cancer cells. Altogether, we have observed that while IRDye 800 labeled HER2 DNA aptamer sequences significantly bind to MDA MB 453 and SKBR3 breast cancer cells which express HER2 receptors abundantly, very little nonspecific binding was observed in MDA MB 231 cells which do not express any HER2 receptors.
\end{abstract}

Keywords: Aptamer, Anticancer drug, Breast cancer, HER2, Fluorophore

\footnotetext{
${ }^{1}$ İstanbul Üniversitesi Sağlık Bilimleri Enstitüsü

2 İstanbul Aydın Üniversitesi Tıp Fakültesi, Tıbbi Farmakoloji Anabilim Dalı

Yazışma Adresi: Dr. Nedret ALTIOK, İAÜ Tıp Fakültesi Tıbbi Farmakoloji AD, Beşyol Mah. İnönü Cad. No:38

Küçükçekmece, İstanbul, Türkiye. Tel: +90 4441428 E-mail: nedretaltiok@aydin.edu.tr

ORCID ID: 0000-0001-5989-8482.

Geliş Tarihi: 17 Şubat 2020 Kabul Tarihi: 03 Mart 2020

Doi num: 10.17932/IAU.TFK.2018.008/2020.301/tfk_v03i1005
} 


\section{Giriş}

HER2 (human epidermal growth factor receptor 2) reseptörünün aşırı ekspresyon ve mutasyonları meme kanseri başta olmak üzere yumurtalık, mide, mesane ve akciğer kanseri gibi çeşitli kanser türleri ile ilişkilendirilmiştir. HER2 gen amplifikasyonu bulunan kanser hücrelerinde, HER2, liganda bağlı olmayan spontan homodimerler veya EGFR/ HER3 reseptörleri ile heterodimerler oluşturarak sitoplazmik kinaz bölgesi konstitutif aktif hale gelir $(1,2,3)$. HER2 reseptörünün aşır1 ekspresyonu meme kanseri ve bazı diğer kanserlerde antikanser ilaçlara direnç gelişmesine ve prognozun kötü olmasına yol açar. $\mathrm{Bu}$ nedenle HER2 reseptörü tümör-spesifik ilaç verilebilmesi için önemli bir hedeftir. Artmış HER2 ekspresyonu olan meme kanseri hastalarının tedavisinde kullanılan trastuzumab, pertuzumab gibi monoklonal antikor yapısındaki hedefe yönelik terapötikler HER2 reseptörünün farklı dimerlerine bağlanarak etki gösterirler, fakat sonradan gelişen ilaç direnci, istenmeyen etkiler ve yüksek fiyatları nedeniyle kullanımları kısıtlıdır.

Son y1llarda aptamer-ilaç kompleksleri, HER2 ve diğer hedef moleküllere yönelik üretilmeye başlamış, tanı ve tedavi amaçlı kullanılma potansiyelleri geliştirilmeye çalışılmaktadır $(4,5)$. Aptamerler; aminoasitler, antibiyotikler, proteinler, nükleik asitler gibi çok çeşitli moleküllere yüksek spesifite ve afinite ile bağlanabilen 100 bazdan k1sa oligonükleotidlerdir. HER2 ekspresyonunun yüksek olması HER2 reseptörüne karşı geliştirilmiş aptamerin daha fazla yoğunlukla bağlanması için gereklidir. Bu amaçla, bu çalışmada yüksek oranda HER2 ekspresyonu olduğunu gösterdiğimiz MDA MB 453 ve SKBR3 meme kanser hücrelerini ve kontrol olarak hiç HER2 ekspresyonu olmadığını saptadığımız MDA MB 231 hücrelerini kullandık.

\section{Gereç ve Yöntem}

\section{Hücre kültürü}

Çalışmada insan meme kanseri hücre soyları MDA MB 453 ve SKBR3 analizler için kullanıldı ve kontrol olarak MDA MB 231 kullanıldı. Hücre soyları ATCC (American Type Culture Collection)'dan alındi. MDA MB 453, MDA MB 231 ve SKBR3 hücreleri DMEM/F12, ve \%10 FBS (fetal bovine serum), 2 $\mathrm{mmol} / \mathrm{L}$ glutamin ve 100 ünite/mL penisilin $\mathrm{G}, 100$ $\mu \mathrm{g} / \mathrm{mL}$ streptomisin içeren medyumlarda $37^{\circ} \mathrm{C}^{\prime} \mathrm{de}$ $\mathrm{CO}_{2}$ inkübatöründe kültüre edildi.
Hücrelere aptamer bağlanması ve hücre içine alınmast

Gastrik tümör hücrelerinde HER2 yüzey antijenlerini tanıdığı bildirilen monomerik ve trimerik HER2 DNA aptamer sekanslarına (6) yakın kızı̈ötesi (Near-Infrared) floresan boya IRD 800 bağlanarak florofor işaretli aptamerin HER2 reseptörüne bağlanması ve internalizasyonu optikal LI-COR ${ }^{\circledR}$ Odyssey ${ }^{\circledR}$ Infrared Imaging Sistemi kullanılarak Hücre Bağlanma yöntemi ile incelendi.

Hücreler microtiter plate'lere deney sırasında \%7080 konfluent olacak sayıda ekildi ve $37^{\circ} \mathrm{C}^{\prime}$ de $\mathrm{CO}_{2}$ inkübatöründe kültüre edildi. $1 \mu \mathrm{M}$ IRD 800 -işaretli aptamerler hücre kültür medyumu ile dilue edildikten sonra hücreler ile 1 saat inkübe edildi. Hücreler PBS ile yıkandıktan sonra metanol ile fikse edildi. Yıkandıktan sonra plate'ler LI-COR $®$ Odyssey® Infrared Imaging Sistemi kullanılarak hücrelere aptamer bağlanması ve hücre içine alınması kantitatif olarak analiz edildi (7).

\section{In Cell western}

IRD 800-işaretli aptamerler ile hücre bağlanma analizi yapılan hücreler metanol ile fiksasyondan sonra PBS $+\% 0.1$ Triton X-100 ile yıkand 1 ve 1 saat bloke edildi. Sonra anti HER2 primer antikoru ile oda 1sısında 2 saat inkübe edildi. 1x PBS $+\% 0.1$ Tween-20 yıkamalarından sonra anti rabbit $680 \mathrm{RD}$ işaretli sekonder antikor ile 1 saat inkübe edildi. Hücreler 1x PBS + \%0.1 Tween-20 y1kamalarından sonra LI-COR® Odyssey ${ }^{\circledR} \quad$ Infrared Imaging Sistemi kullanılarak görüntülendi.

\section{Immunofloresan}

HER2, ekspresyonunu göstermek için hücreler coverslipler üzerine ekildi. Yaklaşık \%80 konfluent hale gelince 1x PBS ile yıkanıp metanol ile $-20^{\circ} \mathrm{C}$ ' de 10 dakika fikse edildi. $1 \mathrm{x}$ PBS $+\% 0.1$ Triton X-100 ile yıkanıp, 1 saat bloke edildikten sonra anti-HER2 primer antikoru ile oda 1sısında 2 saat inkübe edildi. $1 \mathrm{x}$ PBS $+\% 0.1$ Tween-20 y1kamalarından sonra anti rabbit Alexa Flour 594 işaretli sekonder antikor ile 1 saat inkübe edildi. Son 10 dakikada nükleer görüntüleme için DAPI eklendi ve hücreler PBS + Tween 20 yıkamalarından sonra Leica floresan mikroskop ile görüntülendi.

Fluoresan mikroskopta infrared IRD 800 işaretli HER2 DNA aptamerleri görüntülemek için uygun filtre bulunamadığı için trimerik (42 nükleotid) 
sekansin 5'ucuna IRD 800 yerine Alexa Flour 488 bağlanarak işaretlendi ve floresan mikroskop ile Alexa Flour 488 işaretli HER2 DNA trimerik aptamerlerin (HER2 t Alexa Flour 488) hücreler üzerindeki lokalizasyonu incelendi.

\section{Bulgular}

HER2 DNA aptamer sekanslarını referans aldığımız Mahlknecht ve arkadaşları tarafindan gastrik tümör hücrelerinde HER2 yüzey antijenlerini tanıdığ 1 bildirilen monomerik ve trimerik HER2 DNA aptamer sekanslarının (6) HER2 reseptör ekspresyonu olan meme kanser hücrelerine selektif olarak bağlanıp bağlanmadığını test etmek istedik. $\mathrm{Bu}$ nedenle HER2 DNA aptamer monomerik (14 nükleotid) veya trimerik (42 nükleotid) sekansların 5 'ucuna IRD 800 bağlanarak işaretlendi. IRD 800 işaretli monomerik ve trimerik HER2 DNA aptamer sekanslarının meme kanser hücrelerinde HER2 reseptörlerini hedefleme yetenekleri LI-COR ${ }^{\circledR}$ Odyssey® Infrared Imaging Sistemi kullanılarak Hücre Bağlanma (Cell Binding) analizi ve In Cell western yöntemleri ile karşılaştırıldı.

Buna göre, antirabbit 680 RD işaretli sekonder antikor ile In Cell western analizinde görüntülediğimizHER2 reseptör protein düzeylerine (Şekil 1 A, B, C, sağ panel, kırmızı renk) paralel olarak, IRD 800 işaretli monomerik (HER2 IRD 800) ve trimerik (HER2 t IRD 800) DNA aptamer sekanslarının, hiç HER2 ekspresyonu görülmeyen MDA MB 231 hücrelerine bağlanmazken, yüksek oranda HER2 ekspresyonu görülen MDA MB 453 ve SKBR3 meme kanser hücrelerine bağlandıkları görüldü (Şekil 1 A, B, C, sol panel, yeşil renk). IRD 800 işaretli monomerik ve trimerik aptamer sekansları arasında HER2 reseptörlerine bağlanma afinitelerinde bir farkl1lık gözlenmedi.

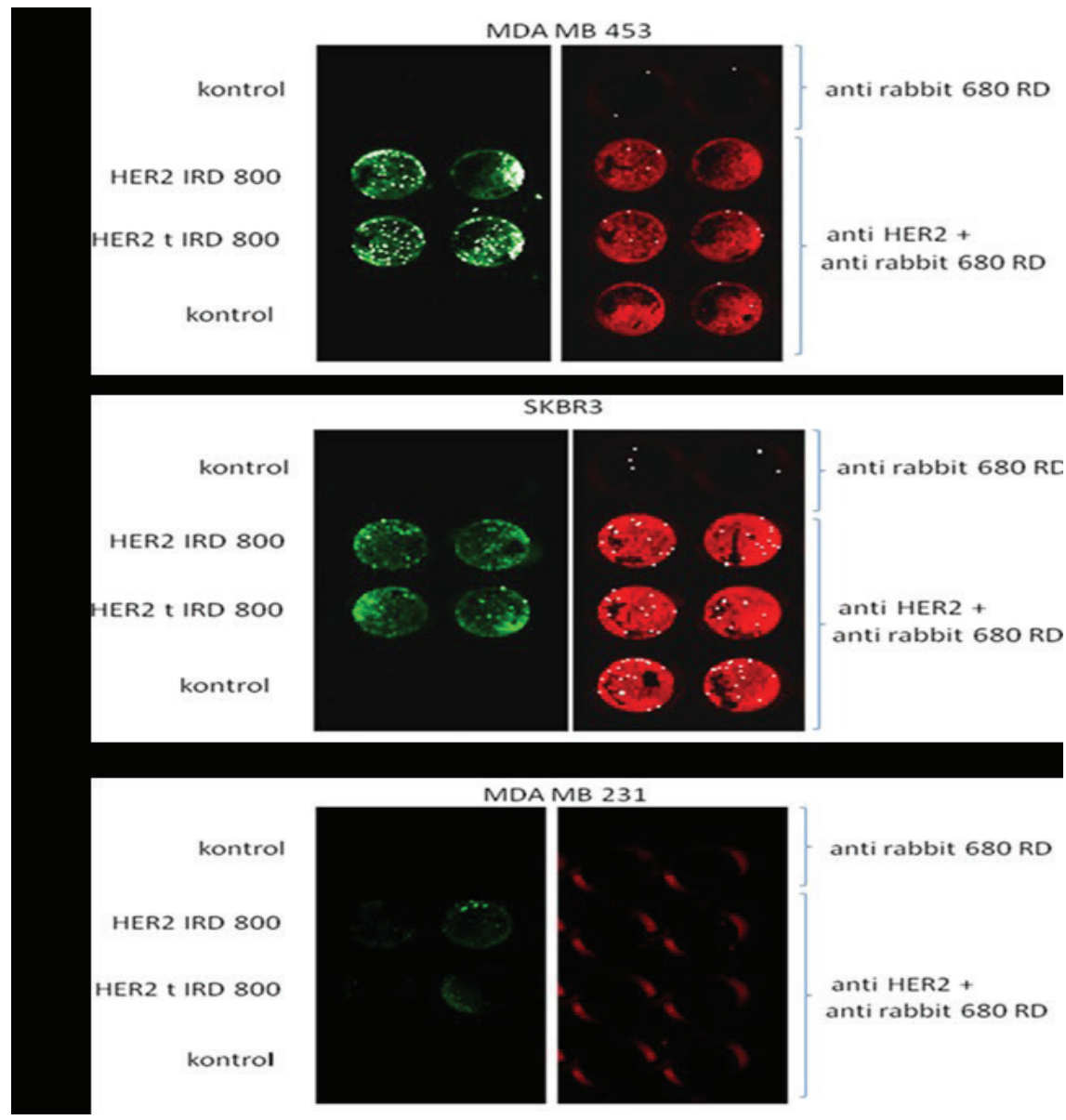

Şekil 1. Hücre Bağlanma ve In Cell western analizleri. IRD 800 işaretli monomerik(HER2 IRD 800) ve trimerik (HER2 t IRD 800) DNA aptamer. 
Yukarıda LI-COR® Odyssey® Infrared Imaging Sisteminde Hücre Bağlanma ve In Cell western analizlerinde IRD 800 işaretli monomerik ve trimerik aptamer sekanslarının HER2 reseptörlerinin bulunduğu hücrelere bağlandığını saptadıktan sonra aptamerlerin lokalizasyonunu Fluoresan mikroskop ile incelemeye karar verdik.

Fluoresan mikroskopta infrared IRD 800 işaretli HER2 DNA aptamerleri görüntülemek için uygun filtre bulunamadığı için trimerik (42 nükleotid) sekansin 5'ucuna IRD 800 yerine Alexa Flour 488 bağlanarak işaretlendi ve floresan mikroskop ile Alexa Flour 488 işaretli HER2 DNA trimerik aptamerlerin (HER2 t Alexa Flour 488) hücreler üzerindeki lokalizasyonu incelendi. Şekil 2, üst panelde görüldüğ̈ gibi Alexa Flour 488 işaretli trimerikHER2 aptamerlerin, HER2 overekspresyonu olan MDA MB 453 ve SKBR3 hücrelerine alt paneldeki HER2 reseptörlerinin lokalizasyonuna paralel şekilde periferik olarak bağlandığı görüldü. Hiç HER2 ekspresyonu görülmeyen MDA MB 231 hücrelerine ise hiç bağlanma görülmedi (DAPI dışında alanlar tamamen karanlık olduğu için Şekil 2'te gösterilmedi). Bu bulgular, HER2 DNA aptamerlerin meme kanser hücrelerinde hücre membranında bulunan HER2 reseptörlerine selektif olarak bağlandığını ilk defa lokalizasyon olarak göstermiştir. Şekil 2'de hücre nukleusları mavi renkte DAPI ile görüntülenirken alt panelde HER2 proteinleri hücre membranında anti HER2 primer antikor ve anti rabbit Alexa Flour 594 sekonder antikoru ile kırmızı renkte görüntülendi (Şekil 2. a,b: HER2 t Alexa Flour 488; c,d: anti rabbit Alexa Flour 594).

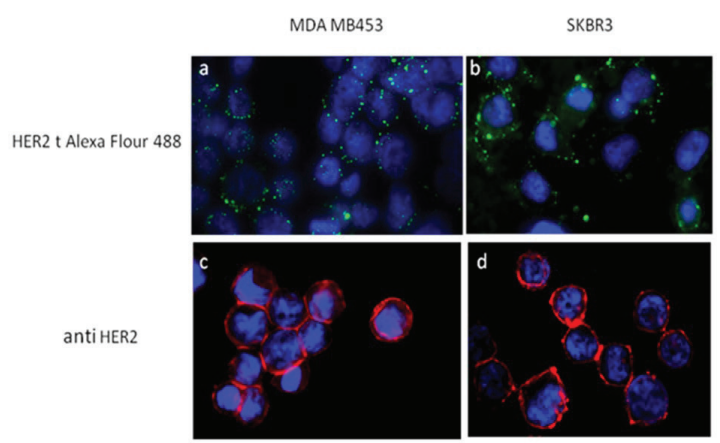

Şekil 2. Floresan mikroskop görüntüleri. a,b: HER2 t Alexa Flour 488; c,d: anti HER2+ anti rabbit Alexa Flour 594

\section{Tartışma ve Sonuç}

$\mathrm{Bu}$ bulgular, bu çalışmada kullandığımız HER2 DNA aptamer sekanslarının HER2+ meme kanser hastalarında ileride diyagnostik ve/veya terapötik amaçlarla kullanılabilecek selektivitede olduğunu göstermektedir.

HER2+ metastatik meme kanseri tedavisinde kemoterapötikler dışında onaylanmış 4 hedefe yönelik tedavi vardır. Bunlar, anti-HER2 monoklonal antikorlar; trastuzumab (Herceptin, Genentech), TDM-1 (trastuzumab emtansine) (Kadcyla, Genentech), pertuzumab (Perjeta, Genentech), ve tirozin kinaz inhibitörleri; neratinib (Nerlynx, Puma Biotech) ve lapatinib (Tykerb, GlaxoSmithKline)dir.

Fakat bu ilaçlara direnç geliştirmiş metastatik meme kanser hastalarında bu ilaçların birlikte kullanılması ciddi toksik ve ölümcül yan etkilerin ortaya çıkmasına yol açmaktadır ve tedavi çok pahalıdır. $\mathrm{Bu}$ nedenlerle HER2+ meme kanseri tedavisinde HER2 reseptörünü hedefleyen daha selektif, etkili, ve toksik yan etkilerin az olduğu tedavi stratejilerine gerek vardır $(8,9)$. Bu çalışmada kullandığımız strateji, farklı kanserlerde yüzey antijenlerine karşı aptamer bazlı tanı ve tedavi yöntemlerinin geliştirilmesine öncülük edebilecektir.

Bu çalışmadaki bulgular, DNA aptamerlerin meme kanseri ve diğer kanserlerin tedavisinde kullanılmak üzere HER2 ve diğer hücre yüzey proteinlerine yönelik klinikte kullanılmakta olan monoklonal antikor veya küçük molekül tirozin kinaz inhibitörü ilaçlardan daha yüksek spesifite ve afinitede ve dolayısı ile toksik yan etkileri azaltılmış yeni ilaç geliştirilme stratejisi olabileceğini göstermektedir. HER2-pozitif kanser hastalarında hedefe yönelik ilaç verilebilmesi amacılya kanser hücrelerine tümör-spesifik şekilde aptamer ile konjuge edilerek sitotoksik ilaçların taşınmasını sağlayacak olması yanında, florofor işaretli aptamerin kullanılması ile moleküler görüntüleme alanına da yenilik getirecektir.

Aptamerlerin hedefe spesifik olmaları, kolayca seçilip sentez edilebilmeleri, çeşitli modifikasyonların kolayca yapılabilmesi, rekombinant sistemlere gerek duymamaları, $\mathrm{pH}$ 
ve 1Sı değişikliklerine dayanıklı ve ucuz olmaları nedeniyle bu strateji, klinik uygulamada HER2pozitif tümörlerde yeni bir tanı ve/veya tedavi yöntemi olarak ortaya çıkabilecektir.

*Bu proje TÜBITTAK (proje no:114S517) tarafindan desteklenmiştir.

\section{KAYNAKLAR}

1. Altiok N, Bessereau JL, Changeux, JP. ErbB3 and ErbB2/neu mediate the effect of heregulin on acetylcholine receptor gene expresssion in muscle: differential expression at the endplate. EMBO Journal 1995;14(17):4258-66.

2. Baselga J, Swain SM. Novel anticancer targets: revisiting ERBB2 and discovering ERBB3. Nat Rev Cancer 2009;9:463-75.

3. Wilson TR, Fridlyand J, Yan Y et al. Widespread potential for growth-factor-driven resistance to anticancerkinase inhibitors. Nature 2012;487:505-9.

4. Gijs M, Penner G, Blackler GB et al. Improved Aptamers for the Diagnosis and Potential Treatment of HER2-Positive Cancer. Pharmaceuticals 2016; 9:29.
5. Zhu G, Zhang H, Jacobson O et al. Combinatorial Screening of DNA Aptamers for Molecular Imaging of HER2 in Cancer", Bioconjug Chem 2017; 28(4):1068-75.

6. Mahlknecht $G$, Maron $R$, Mancini $M$ et al. Aptamer to ErbB-2/HER2 enhances degradation of the target and inhibits tumorigenic growth. Proc Natl Acad Sci USA 2013; 110(20):8170-75.

7. Gong H, Kovar J, Little $\mathrm{G}$ et al. In vivo imaging of xenograft tumors using an epidermal growth factor receptor-specific affibody molecule labeled with a near-infrared fluorophore. Neoplasia 2010; 12:139-49.

8. Dent S, Oyan B, Honig A et al. HER2-targeted therapy in breast cancer: A systematic review of neoadjuvant trials. Cancer Treatment Reviews 2013; 39:622-31.

9. Kümler I, Tuxen MK, Nielsen DL. A systematic review of dual targeting in HER2-positive breast cancer. Cancer Treatment Reviews 2014; 40(2);25970 . 